*ak RMIS View/Frint Document Cover Sheet tow

This document was retrieved from the Documentation and Records Manaqement (DRM) ISEARCH System. It is intended for Information only and may not be the most recent or updated version. Contact a Document Service Center (see Hanford Info for locations) if you need additional retrieval information.

Accession \#: D196004702

Document \#: SD-EN-FDC-002

Title/Desc:

FDC FOR FY1993-2000 GROUNDWATER MONITORING WELLS 93-L-GFW-152

Pages: 39 


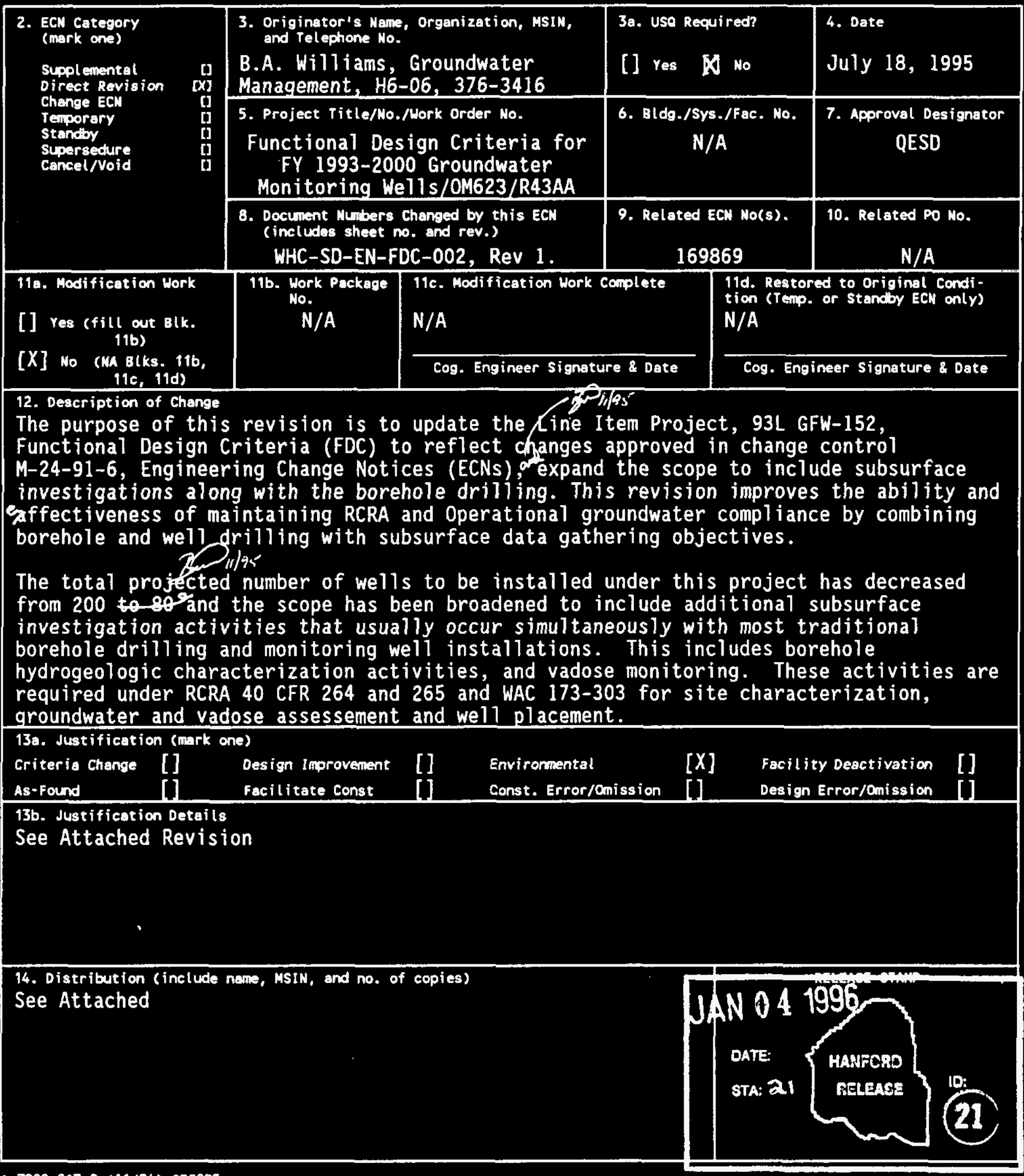

A-7900-013-2 (11/94) GEF095 


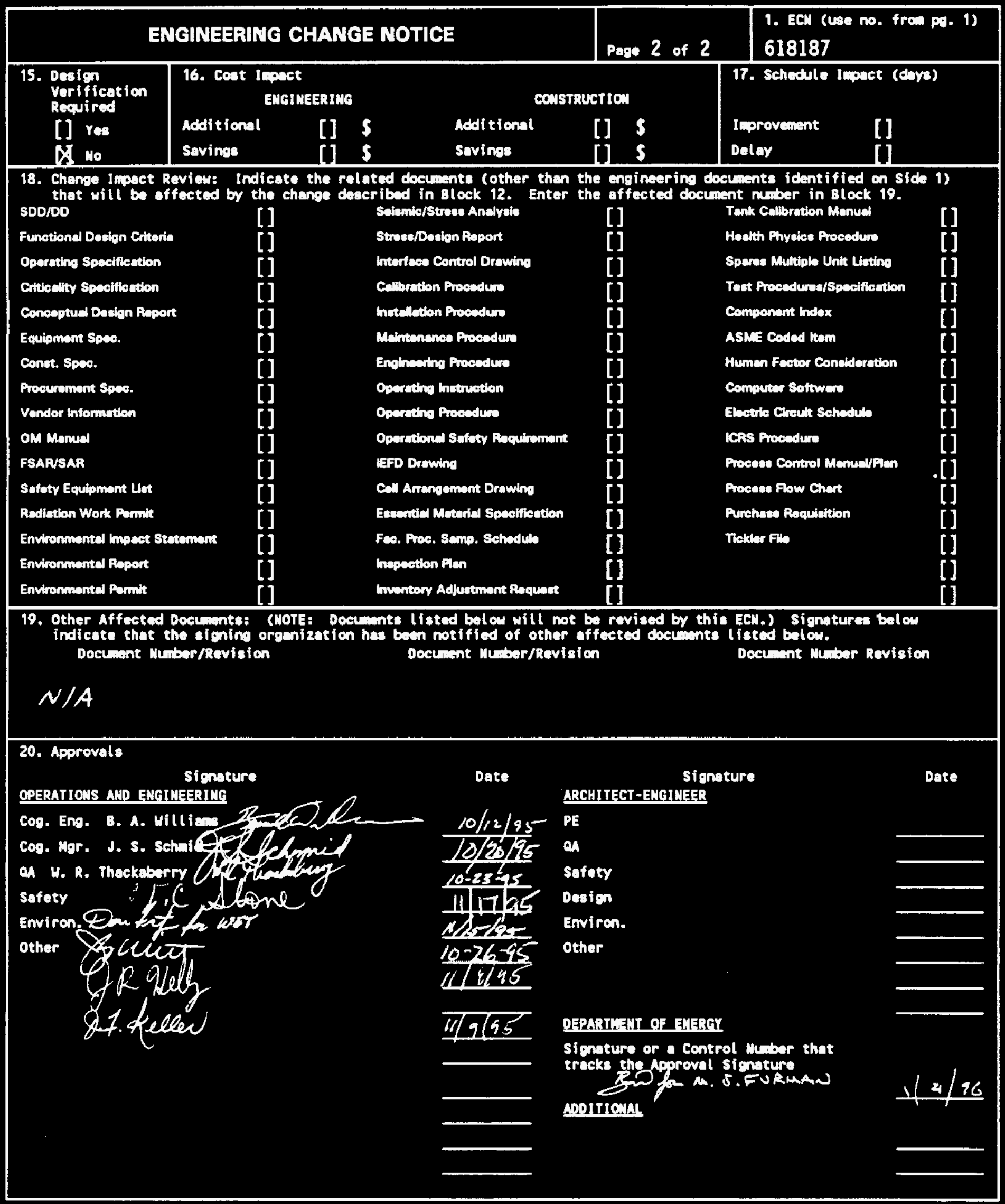




\title{
Functional Design Criteria for FY 1993-2000 Groundwater Monitoring Wells
}

\author{
B. A. Williams
}

Westinghouse Hanford Company, Richland, WA 99352

U.S. Department of Energy Contract DE-AC06-87RL10930

\author{
EDT/ECN: $\quad$ ECN-618187 UC: 2000 \\ Org Code: W8H230 Charge Code: R4069 \\ B\&R Code: EW5010006 Total Pages: 35
}

Key Words: RCRA wells, design criteria, borehole drilling. characterization

\section{Abstract:}

The purpose of this revision is to update the Line Item Project, 93-L-GFW-152 functional Design Criteria (FDC) to reflect changes approved in change control $\$-24-91-6$, Engineering change Notices (ECNs), and expand the scope to include subsurface investigations along with the borehole drilling. This revision ilproved the ability and effectiveness of maintaining RCRA and operational groundwater compliance by combining borehole and well drilling with subsurface data gathering objectives.

The total projected number of wells to be installed under this project has decreased from 200 and the scope has been brosdened to include additional subsurface investigation activities that usually occur simultaneously with most treditional borehole drilling and monitoring well installations. This includes borehole hydroseologic characterization activities, and vadose rilonitoring. These activities are required under RCRA 40 CFR 264 and 265 and WAC 173-303 for site characterization, grounduater and vadose assessuent and well placentent.

TRADEMARK DISCLAIMER. Reference herein to any specific commercial product, process, or service by trade nawe, tradinark, manufacturer, or otherwise, does not necessarily constitute or inply its endorseinent, reccinlendation, or favoring by the United States covernment or any agency thereof or its contractors or subcontractors.

Printed in the United States of Marica. To obtain copies of this document, contact: WHC/BCS Document Control Services, P.O. Box 1970, Wailstop H6-08, Richland ill oxz52 Phone-(509) 372-2420; Fax (509) 376-4989.
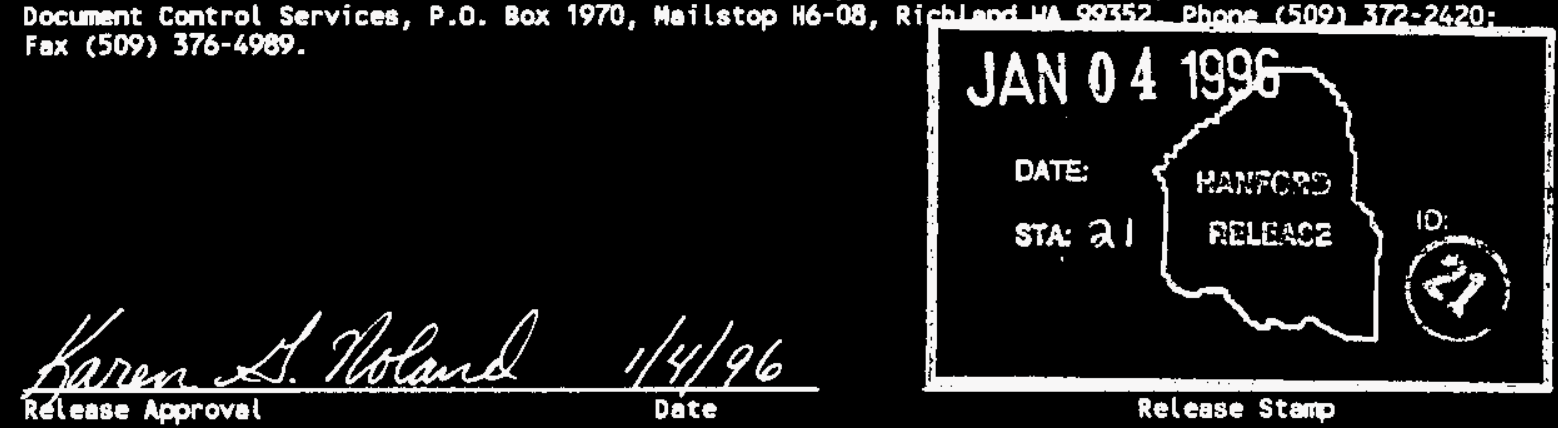

Approved for Public Release 


\section{RECORD OF REVISION}

(1) Doceunt Mumber

WHC-SD-EN-FDC-002

(2) Title

Functional Design Criteria for FY 1993-2000 Groundwater Monitoring Wells

CHANAE CONTROL RECOAP

\section{(3) Revision}

(4) (7)

Rev. $\mathbf{0}$

Rev. IRS
EDT \#123605, 8/20/91.

Complete FDC revision (ECN $\# 618187$

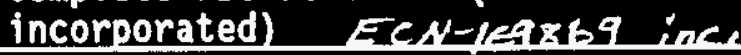

Authorized for Release

(5) Cor. Ent. (6) Co\%. Mor. Date

B.A. D.G.Horton

Willians

B.Avil]ians $\mathcal{S}$. S. Bchmid 


\section{Functional Design Criteria for Fiscal Years 1993 through 2000 Groundwater Monitoring Wells 93-L-GFW-152}

Prepared for the U.S. Department of Energy Office of Environmental Restoration and Waste Managament

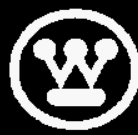

U.S. Depertment of Encrey under Contrect DE-AC06-87RL10830 
WHC-SD-EN-FDC-002, Rev 1

FUNCTIONAL DESIGN CRITERIA FOR

FISCAL YEARS 1993 THROUGH 2000 GROUNDWATER MONITORING WELLS 93L-GFW-152

\author{
Issued by \\ Westinghouse Hanford Company \\ June 1990 \\ Revised June 1995 \\ for the \\ U.S. Department of Energy \\ Richl and Operations Office \\ Richl and, Washington
}




\section{WHC-SD-EN-FDC-002, Rev 1}

Prepared by:

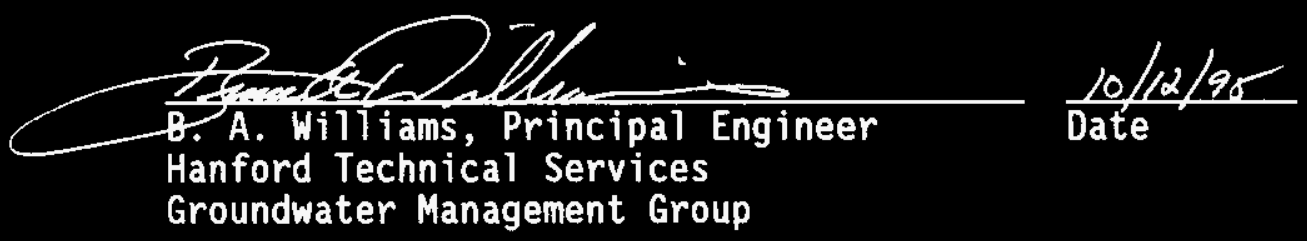

Westinghouse Hanford Company Approvals:

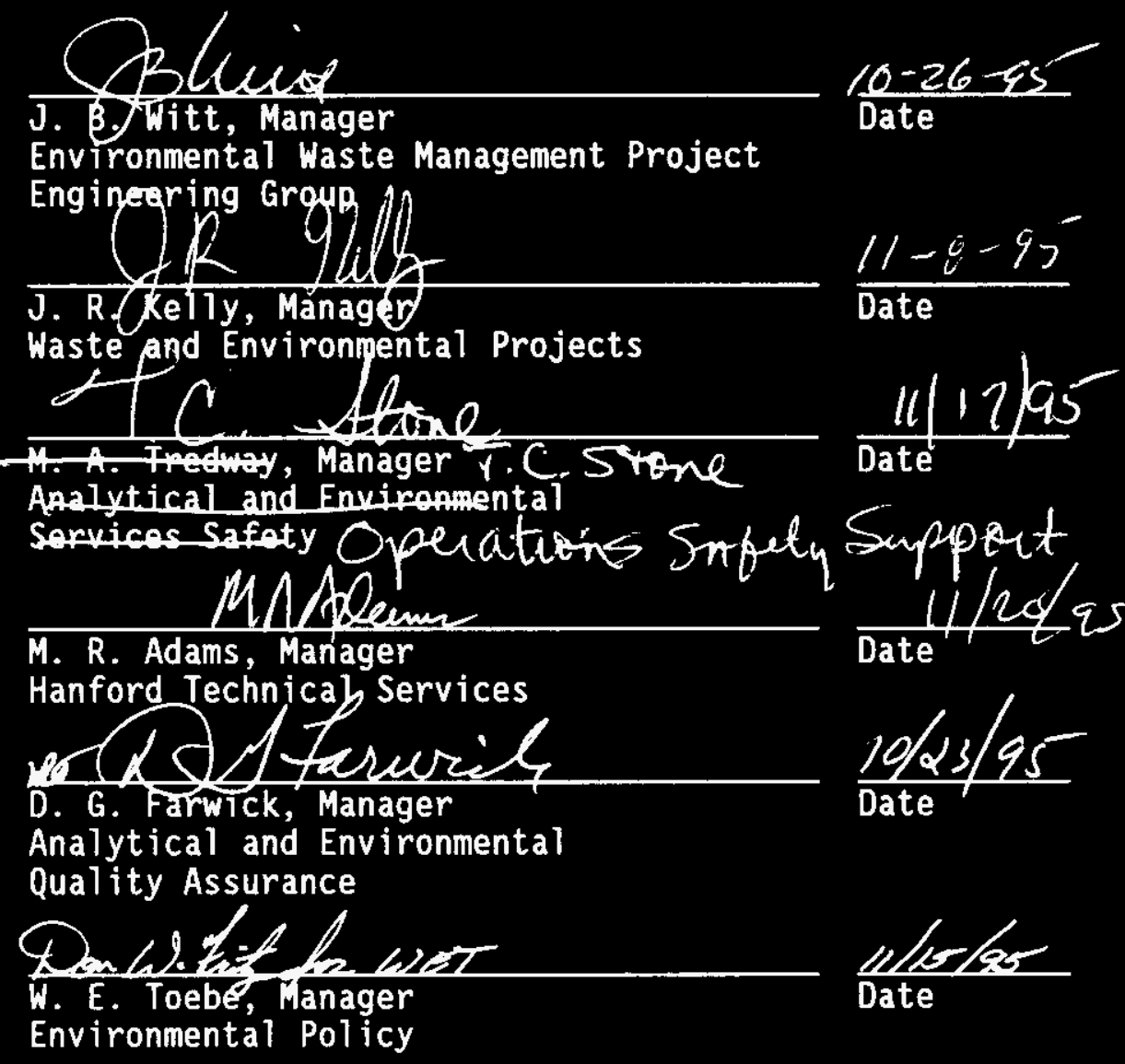

U.S. Department of Energy-Richland Operations Office Approval:

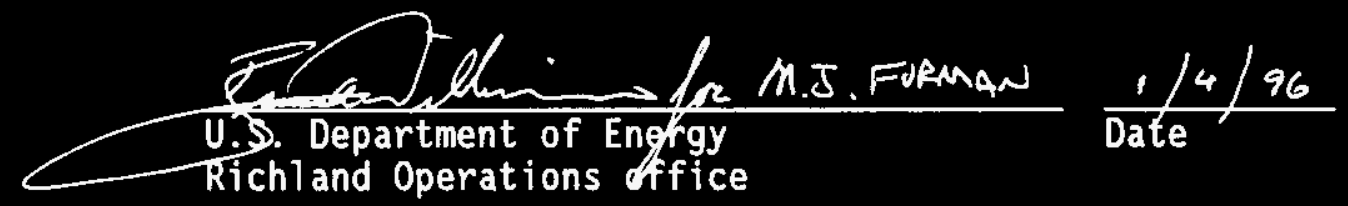


TABLE OF CONTENTS

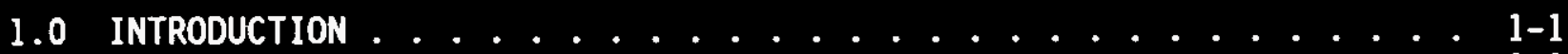

1.1 SCOPE . . ...................... 1-

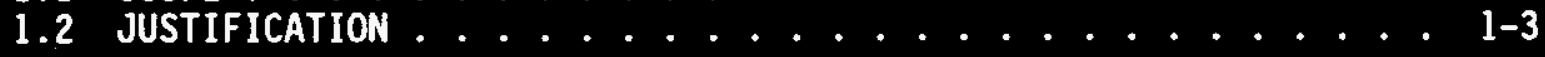

2.0 FUNCTIONAL CRITERIA ................ 2-1

2.1 SITE LOCATION ................. 2-1

2.2 DECOMHISSIONING ..................... 2- .

3.0 PROCESS DESIGN CRITERIA . . . . . . . . . . 3-1

4.0 MELL DESIGN CRITERIA ................. 4-1

4.1 ARCHITECTURAL ................. 4-1

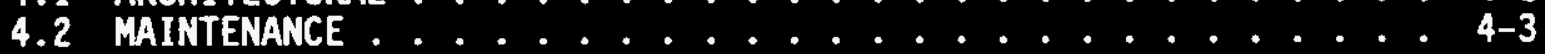

5.0 GENERAL REqUIREMENTS . . . . . . . . . . . . 5-1

5.1 SAFETY . . . . . . . . . . . . 5-1

5.1.1 Safety Analysis ............ 5-1

5.1.2 Environmental Protection ........... 5-1

5.1 .3 Contamination Control ............. 5-2

5.1 .4 Shielding .............. 5-2

5.2 SAFEGUARDS AND SECURITY .............. 5-2

5.3 DESIGN FORMAT ................ 5-2

5.4 QUALITY ASSURANCE . . . . . . . . . . . 5-3

5.4.1 Qual ity Assurance Onsite .......... 5-3

5.4 .2 Interface Coordination ........... 5-3

6.0 CODES AND STANDARDS . . . . . . . . . . . 6-1

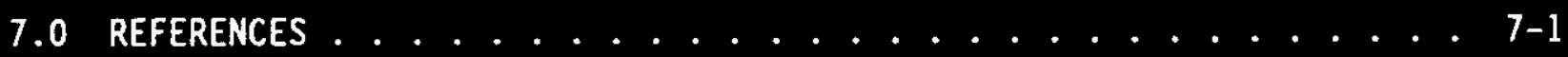

\section{APPENDIX}

A DeSIGN GUIDANCE ................... A-i 


\section{LIST OF TERHS}

$\begin{array}{ll}\text { CERCLA } & \text { Comprehensive Environmental Response, Compensation, and } \\ & \text { Liability Act } \\ \text { CFR } & \text { Code of Federal Regulation } \\ \text { CX } & \text { categorical exclusion } \\ \text { DOE } & \text { U.S. Department of Energy } \\ \text { DOE-RL } & \text { U.S. Department of Energy, Richland Operations Office } \\ \text { ECology } & \text { Washington State Departient of Ecology } \\ \text { EPA } & \text { U.S. Environmental Protection Agency } \\ \text { FOC } & \text { Functional Design Criteria } \\ \text { FY } & \text { fiscal year } \\ \text { HASP } & \text { health and safety plans } \\ \text { HSWA } & \text { Hazardous and Solid Waste Amendment of 1989 } \\ \text { NEPA } & \text { National Environmental Pol icy Act of 1969 } \\ \text { rad/chem } & \text { radiological and chemical } \\ \text { RCRA } & \text { Resource Conservation and Recovery Act of 1976 } \\ \text { SALDS } & \text { State Approved Land Disposal System } \\ \text { TEDF } & \text { Treated Effluent Discharge Facility } \\ \text { TEGD } & \text { RCRA Technical Enforcement Guidance Document } \\ \text { Tri-Party } & \text { Hanford Federal Facility Agreement and Consent Order } \\ \text { Agreement } & \text { treatment, storage, and disposal } \\ \text { TSD } & \text { Washington Administrative Code } \\ \text { WAC } & \text { Westinghouse Hanford Company } \\ \text { WHC } & \text { Waste Management Operations } \\ \text { WMO } & \text { waste management unit } \\ \text { WMU } & \end{array}$




\author{
WHC-SD-EN-FDC-002, Rev 1 \\ FUMTIOML DESICY CRITERIA \\ FOR FISCAL YEMRS 1993 THROVYH 2000 \\ EROLDUATER MUNTTORING MELLS
}

\title{
1.0 IKTRODUCTION
}

This document addresses the Functional Design Criteria (FDC) for the construction of monitoring wells (groundwater and vadose) under the Resource Conservation and Recovery Act of 1976 (RCRA) and Operational Groundwater Monitoring program (ROM) from Fiscal Years (FY) 1993 through 2000 (DOE 1989).

The ROM provides early detection and near-field assessment of Hanford Site operations on groundwater quality. U.S. Department of Energy (DOE) Order 5480.4, Environaental Protection, Safety, and Health Protection Standards (OOE 1984), Federal (Title 40, Code of Federal Regulation [CFR], Part 264, Subpart F and 40 CFR 265 Subpart F), and state environmental regulations (Washington Adninistrative Code [WAC] 173-160, WAC 173-303, WAC 173-304) require nonitoring wells to be installed around RCRA treatment, storage, and disposal (TSD) units and solid waste landfill facilities. The Washington State Department of Ecology (Ecology) requires that permitted effluent discharge facilities at the Hanford Site install groundwater monitoring wells. DOE Order 5400.1 (IV) (DOE 1988), Westinghouse Hanford Company (WHC) controlled manuals WHC-CM-7-4 and HHC-CM-7-5, and as described in the Environmental Monitoring Plan for the Hanford Site (DOE, Richland Operations office [DOE-RL] 1994) also require near-field operational (sites not covered by state discharge permits, RCRA or Comprehensive Environmental Response, Compensation, and Liability Act [CERCLA]) groundwater monitoring in support of Waste Managenent Operations (WMO) operational monitoring.

Borehole drilling and well installation provide access to the subsurface for vadose and groundwater monitoring. These activities also provide for hydrogeologic characterization of the subsurface, including identification of preferential vadose and groundwater flow paths, identification of the uppermost aquifer properties (including confining boundaries), and radiological and chemical (rad/chem) data acquisition to determine whether a facility or TSD unit affects the aquifer (contaminant assessment).

\subsection{SCOPE}

This revision to Project 93L-GFH-152 (Project H-152) will cover the requirements for borehole drilling/probing, hydrogeologic data gathering, and well installation at RCRA TSD units, operational sites, and for related environmental testing that supports the ROM program. This FDC covers those monitoring wells that will be constructed in FY 1993 through 2000 (as modified in Project $\mathrm{W}-152$ Basel ine Change Request W-152-014.1).

Less than 15 wells are anticipated to be drilled in any remaining project year. This estimate is based on the monitoring status of TSD units and operational facilities and sites. Results and evaluations from ongoing TSD 
unit sampling and analysis, continued hydrogeologic assessment, and declining water levels provide the basis for these additional well requirements.

The installation of groundwater monitoring networks at RCRA TSD units is scheduled and prioritized in the legally binding Hanford Federal Facility Agreenent and Consent Order (Tri-Party Agreement), (Ecology et al. 1994) Action Plan, and in permitting documents for meeting RCRA permitting needs at the Hanford Site. A change to the Tri-Party Agreement (M-24-91-6) was issued in November 1991 reducing the 50-we11-per-year requirement to well installations "as needed," as defined and approved in yearly interim milestones. The Tri-Party Agreement requires that wells be installed around RCRA TSD units until RCRA-compliant monitoring systems are completed.

Project $\mathrm{W}-152$ also covers operational wells needed to support WMO. The Hazardous and Solid Waste Amendment of 1989 (HSWA 3004 [U]) provides that any permit issued after November 8, 1984, must require corrective action for al1 releases of hazardous waste or constituents from any solid waste management unit (WMU) (operational sites) regardless of when the waste was placed at the unit. This action will require additional subsurface data gathering and monitoring well installations around affected operational sites undergoing continuing, new, or expanding operations. Operational groundwater well needs are defined and approved through ongoing state negotiated waste discharge permit applications (i.e., State Approved Land Disposal System [SALDS] and the Treated Effluent Discharge Facility [TEDF]). In addition, DOE has ongoing facility impact assessments (i.e., 100-K Fuel Storage Basins) that require groundwater and vadose monitoring support. It is important to plan additional wells at these operations to ensure that Federal and state monitoring requirements are met.

Project $\mathrm{W}-152$ also will support well installation for special engineering needs to support environmental testing programs such as Hanford Site background/baseline studies, flowmeter and vertical profiling studies, and facility citing studies.

This document provides requirements for subsurface hydrogeologic characterization, rad/chem data acquisition, and well installations for groundwater and vadose monitoring systems for hazardous, mixed, and radioactive waste disposal sites. The gathering of characterization data during well drilling and construction is necessary to establish the pedigree of the well to ensure that it is fit for the intended use. This practice is equivalent to acquiring certified materials test reports or testing results for construction of systems requiring specified safety and design factors. The value and design of the well is diminished greatly (less defensible) without the supporting data to establish the wells effectiveness, to sample the appropriate portion of the aquifer, and to confirm that construction is in accordance with the regulatory requirements. When completed, monitoring systems sha11 comply with RCRA regulations and laws for well construction and groundwater monitoring as described in WAC 173-160 and 173-303, and 40 CFR Parts 264 and 265. Other requirements for monitoring wells are found in applicable DOE orders related to groundwater monitoring of radionuclide waste disposal sites. 


\subsection{JUSTIFICATION}

DOE Order 5480.4 states that DOE facilities will comply with environmental regulations and laws, and monitor the groundwater to detect and assess any potential contamination from its operations and activities. The Tri-Party Agreement, which was signed by DOE, Ecology, and U.S. Environmental Protection Agency (EPA), is a guiding document for this effort. Commitments were made in the Tri-Party Agreement for installing groundwater monitoring wells for RCRA sites (Milestone M-24-00). Failure to meet Tri-Party Agreement milestones could result in fines and legal action by the EPA and Ecology, which would have a negative impact on all Hanford Site activities. 
WHC-SD-EN-FDC-002, Rev 1

This page intentionally left blank. 
WHC-SD-EN-FDC-002, Rev 1

\subsection{FUMCTIOML CRITERIA}

Project W-152 will provide groundwater and vadose monitoring systems for RCRA and operational facilities throughout the Hanford Site. Monitoring wells around TSDs and operational WMUs are prioritized in accordance with Tri-Party Agreement milestones, permitting documents, and programmatic commitments. Tri-Party Agreement interim milestones will designate the number of monitoring wells that will be installed at each unit. The design and construction of any well must meet Ecology requirements set forth in WAC 173-160 and WAC 173-162.

The completed monitoring system must meet the applicable functional criteria identified in WAC 173-303-645, 40 CFR 264 Subpart F, and 40 CFR 265 Subpart F, for interim- and final-status facilities and applicable and appropriate regulatory guidel ines provided in the RCRA Technical Enforcement Guidance Document (TEGD) (EPA 1986). Functional criteria for well installation activities, including requirements from these regulatory documents, are summarized in the following list with the source of each criterion listed in parenthesis at the end of its description:

- The groundwater monitoring system must be capable of yielding groundwater samples for analys is that are representative of water quality in the uppermost aquifer ( 40 CFR 265)

- Site characterization must include enough hydrogeologic information to determine potential pathways of constituent migration, including ident ifying aquifer intercommunication pathways, hydrogeologic parameters, and aquifer boundaries, including those of deeper aquifers that may be associated with the uppermost aquifer (TEGD)

- At least one monitoring well must be installed hydraulically upgradient from the waste management area. That well will provide groundwater samples from the uppermost aquifer with water quality not affected by the facility (40 CFR 265)

- At least three monitoring wells must be installed hydraulically downgradient of the waste management area. The number, location, and depth must ensure that the wells detect any statistically significant amounts of hazardous waste or hazardous waste constituents that may migrate from the waste management area to the uppermost aquifer (40 CFR 265)

- Monitoring wells shall have a design life to include the active life of the disposal facility plus the 30-year post-closure period (40 CFR 265).

Specific criteria for TSD unit characterization and installation of RCRA wells are found in the RCRA TEGD and in RCRA Groundwater Monitoring: Draft Technical Guidance (EPA 1992). 
WHC-SD-EN-FDC-002, Rev 1

\subsection{SITE LOCATION}

Monitoring wells installed between FYs 1993 and 2000 will be located at TSO units, such as those identified in the current Appendix B (not attached) of the Tri-Party Agreement Action Plan, and at existing or new operational sites that require Ecology- or EPA-compliant monitoring, and are not currently listed in the Tri-Party Agreement. Strategic placement of the wells is needed to complete site hydrogeologic characterization, support vadose monitoring, and immediately detect contaminant releases and migration from a TSD unit, thus decreasing the severity and impact of the release.

Monitoring wells will be located in the $100,200,300,600$, and 1100 Areas. Current RCRA sites that require monitoring networks, as identified in Part $A$ permit applications, are the following:

- 100-D Ponds

- 183-H Solar Evaporation Basin

- 200 Area Low-level Burial Ground

- 200 East Area Liquid Effluent Retention Facility

- 216-A-10 Crib

- 216-A-29 Ditch

- 216-A-36B Crib

- 216-A-37-1 Crib

- 216-B-3 Pond

- 216-B-63 Trench

- 216-U-12 Crib

- 216-S-10 Pond and Ditch

- 300 Area process trenches

- 1301-N Liquid Waste Disposal Facility

- 1324-N/NA basins

- 1325-N Liquid Waste Disposal Facility

- 2101-M Pond

- Nonradioactive dangerous waste landfill

- Single-shell tanks.

Current state and Operational Sites that require monitoring are the following:

- Solid waste landfill

- $100 \mathrm{~K}$ fuel storage basins

- 200 Area Effluent Treatment Facility

- 200 Area Treated Effluent Disposal Facility

- 200 Area 222-S Laboratory

- 216-S-26 Crib

- 400 Area ponds

- 216-B-62 Crib

- Plutonium Uranium Extraction cribs

- U and T Plant cribs and ditches.

Monitoring sites, along with the specific well locations, are identified through ongoing investigations, permitting, and monitoring programs, and will be identified during future negotiations with the regulators. These sites will be included in the Tri-Party Agreement as the document is reviewed and 
revised annually. Operational wells will be identified and documented in other programmatic documents (e.g., $100 \mathrm{~K}$ Basins Well Installation Plan, state discharge permit applications, etc).

As much foresight as possible should be used to locate and construct the selected monitoring wells to support plausible final compliance monitoring systems, to identify changes to RCRA networks that may require modifications from near-field to semi-regional monitoring, and to support the coordination and integration with other Hanford Site monitoring projects. This will maximize the cost effectiveness and long-term efficiency of the system.

\subsection{DECONHISSIONINS}

The scope of this FDC covers only borehole drilling, characterization, and well installation and does not apply to active maintenance, decommissioning, or abandonment of wells. Well design shall not include any features that would preclude abandonment in accordance with WAC 173-160. Project $W-152$ wells under construction (drilling, characterization, or completion phase) that cannot be completed to meet Ecology requirements will be abandoned in accordance to WAC 173-160 requirements.

RCRA we11s need not be abandoned until designated TSD units are certified closed and post-closure activities are completed in accordance with Federal and state requirements and/or the groundwater is cleaned up to background or the applicable and appropriate standards. 
WHC-SD-EN-FDC-002, Rev 1

This page intentionally left blank. 
WHC-SD-EN-FDC-002, Rev 1

\subsection{PROCESS DESIEN CRITERIA}

Process design is not applicable to well installation and function. 
WHC-SD-EN-FDC-002, Rev 1

This page intentionally left blank. 
WHC-SD-EN-FDC-002, Rev 1

\subsection{NELL DESIEN CRITERIA}

A11 wells will be designed in accordance with WAC 173-160, "Minimum Standards for the Construction and Maintenance of Wells." The drilling of boreholes and the emplacement of monitoring systems, "resource protection wells," is required for characterization, detection, and assessment of hazardous or radioactive substances that might have entered the groundwater at a particular facility. If well screens are not placed appropriately within the aquifer, a contaminant release to the groundwater may migrate undetected, increasing the severity and impact of the release. The hydrogeologic characterization of each unit will dictate the exact screen and casing depth for each well. Refer to Appendix A for additional design guidance. Specific site characterization and data acquisition requirements will be reported in groundwater monitoring plans.

Each TSD unit or operational site will consist of several individual monitoring wells, each of which provides access to the uppermost aquifer system for characterization, data gathering, and collection of representative groundwater samples. TSD unit characterization requirements and existing data will dictate the number and depth of boreholes needed to adequately define the extent and characteristics of the aquifer system including the vadose zone. The requirements for monitoring wells and characterization boreholes will be coordinated and integrated to minimize the number and depth of boreholes at each unit.

Design and construction required by WHC also shall conform to the WHC series of controlled manuals (e.g., WHC-CM-6-1, Standard Engineering Practices, WHC-CM-7-5, Environmental Conpliance Manual, WHC-CM-7-7, Environmental Investigation and Site Characterizations Manual, WHC-CM-4-33, Security Manual, and WHC-S-014, Generic Well Specification) or equivalent procedures or orders. Design and construction efforts shall be in accordance with the latest revisions of the regulations, codes, and standards.

Subsequent changes to regulations, codes, and standards that affect the design shall be evaluated and controlled in accordance with WHC-CM-6-1, EP-2.2, "Engineering Document Change Control."

\subsection{ARCHITECTURAL}

Wells and characterization boreholes shall be drilled, constructed, developed, and tested in a manner that will permit representative sampling and assessment of the subsurface hydrogeologic conditions and environment. The monitoring well design shall incorporate features to protect and preserve the well from normal environmental conditions, operational activities, and subsurface conditions that might cause damage to the monitoring well (WAC 173-160). We11-drilling equipment, and permanent and temporary construction materials, must not introduce contaminants to the soil column/aquifer or permit cross contamination between boreholes or aquifers (WAC 173-160 and 40 CFR 265).

All monitoring wells must be cased and screened with nonreactive materials in a manner that maintains the integrity of the monitoring well. The screen must be packed with filter pack material or sand, where necessary, 
and properly located to enable representative groundwater sample collection at depths where appropriate aquifer flow zones exist (WAC 173-160). Dedicated, nonreactive pumps must be installed to allow purging and sampling of each well.

The annular space (i.e., the space between the borehole and well casing) above the screened interval must be sealed with a suitable material (e.g., cement or bentonite) to prevent contaminant and fluid migration down the annulus (WAC 173-160).

The wells will be designed to allow for routine inspections and camera surveys to assess well conditions.

The installed wells will incorporate one or more of the following features:

- Groundwater sampling using a dedicated pump and assembly for purging and sampling

- Vadose zone sampling/monitoring using various approved direct or indirect methods (i.e., tensiometers or borehole geophysics)

- Water production/injection for varied applications uses a dedicated high-volume pump system

- Piezometric head measurements

- Water level measurements

- Aquifer testing such as slug or constant discharge hydraulic tests, flow meter tests, vertical profiling, and tracer tests.

All unknown, suspect, or known hazardous drilling generated wastes, including drill cuttings, purge water, and decontamination water, must be contained, sampled, and dispositioned according to $\mathrm{WHC}-\mathrm{CM}-7-7$, or appropriate WHC controlled manual series.

The completed monitoring well will be accepted for use as a "resource protection wel1" (as defined in WAC 173-160) only after verification of the following:

1) Representative sampling interval - the verification of a representative interval will be confimed by review of sieve, or recovered core (split spoon or whole core) analys is data, aquifer or flow meter results, and as necessary, rad/chem groundwater sampling results;

2) Effective annular well seal - the verification will be confirmed by review of geophysical and as-built log data, tally of sealing materials placed, or annular pressure testing;

3) Wellhead surface protection - the verification will be confirmed by visual inspection as per the WAC requirements; 
4) Effective aquifer communication - the verification will be confirmed by review of development data, aquifer testing and/or flow meter results.

\subsection{MAINTENANCE}

The monitoring well will be designed to allow for ease of maintenance, access, and use. This FDC covers only the installation of wells and does not apply to future maintenance or remediation requirements. 
WHC-SD-EN-FDC-002, Rev 1

This page intentionally left blank. 
WHC-SD-EN-FDC-002, Rev 1

\subsection{GENERAL REOUTRENENTS}

\subsection{SAFETY}

Hazards associated with the construction of well systems are routine to many industries and generally accepted by the public. During construction of the monitoring wells, applicable and approved health and safety plans (HASP) will be followed to provide for the protection of construction personnel in accordance with MHC-CM-1-10, "Safety Manual," and 29 CFR 1910, "Hazardous Waste Operations and Emergency Response."

Safety documentation of groundwater monitoring wells will assess the potential hazards associated with groundwater monitoring wells in accordance to DOE Order 5481.18 (DOE 1986). A review of specific well installations will be performed before drilling to ensure that the work falls within the bounds of the safety analysis and the controls stated in the safety analysis. The safety analysis will be modified or otherwise revised if unique hazards (radiological and toxicological) are identified in the review. WHC Safety (Industrial Safety and Fire Protection, Health Physics) will review and approve the RCRA Sitewide HASP and appropriate individual site-specific hazardous waste operations permits, job safety analyses, or radiation work permits before drilling.

The safety classification of the groundwater monitoring wells was establ ished in WHC-SD-EN-PLN-001, Safety Class Designation of Groundwater Monitoring Wells. The safety classification complies with WHC-CM-1-3, Management Requirenents and Procedures, MRP 5.46, "Safety Classification of Systems, Components, and Structures."

The acceptability of monitoring well design, construction, and operation under normal conditions shall be evaluated in accordance with the following safety considerations.

\subsubsection{Safoty Analysis}

Well construction and installation activities must meet applicable Occupational Safety and Health Act of 1970 standards. All well site activities will be covered by a site-specific safety plan (29 CFR 1910). Each site-specific safety plan will outline all known and potentially hazardous conditions, safety considerations, and actions that may be required under the given field conditions, or in an emergency situation.

\subsubsection{Environmental Protection}

The design, construction, and operation of a monitoring well shall not result in contamination of the groundwater by radioactive and hazardous waste in excess of requirements specified in WHC-CM-7-5, Environmental Compliance, or WAC 173-303, respectively. 
The design, construction, and operation of a monitoring well shall comply with all applicable requirements of the National Environmental Policy Act of 1969 (NEPA) categorical exclusion (CX) for the installation and monitoring of RCRA and related groundwater monitoring systems at the Hanford Site (DOE-RL 1992).

\subsubsection{Contamination Contro1}

During construction, disposal of any contaninated purge water, sediments, and construction materials or tools shall comply with the following appropriate safety standards and procedures.

A11 contaminated materials must be removed from the drill site and disposed of or decontaminated in accordance with WHC-CM-5-16, Hazardous Waste Managewent. These include the drilling rig, equipment and tools, drill cuttings, decontamination fluids, and disposed samples. Purge water, which includes aquifer test and development water, shall be managed in accordance with WHC-CM-7-7 or WHC-MR-0039, Strategy for Handling and Disposing of Purgewater at the Hanford Site, Washington (WHC 1989). Drill cuttings and slurries shall be managed in accordance with WHC-CM-7-7.

After the well is installed, the surrounding area that was affected by the drilling will be restored as much as possible to original conditions and cleaned up in accordance with DOE Order 6430.1A (DOE 1989).

\subsubsection{Shielding}

During construction activities, exposure of personnel to ionizing radiation and/or hazardous chemical agents shall be less than the levels specified in HSRCM-1, Rev. 2, Hanford Site Radiological Control Manual, and shall not be in excess of the requirements set forth in 29 CFR 1910. Specific exposure levels will be identified and documented in the appropriate site HASP.

\subsection{SAFEEUAROS AMD SECURITY}

The locations of the proposed monitoring systems lie within the 100,200 , 300, 600, and 1100 Areas. Each groundwater well will be protected to prevent damage and unauthorized access per WAC 173-160 and as specified in the Generic Well Specification, WHC-S-014.

\subsection{DESIEN FORMAT}

The format for all groundwater well designs and installation procedures will be verified according to WHC-CM-6-1, EP-4.1, "Design Verification Requirements," and comply with EP-1.2, "Preparation of Engineering Specifications." On completion of the well, all traceable documents (e.g., inspection reports, driller logs, geologists logs, as-built diagrams, and borehole geophysical logs) will be transferred to WHC, tracked, and controlled in accordance with WHC-CM-4-2, QR 17.0, "Qual ity Assurance 
Records." Well data reports (data packages and characterization reports) are prepared and published, as required, by regulations in accordance with WHC-CM-7-8.

The installation of wells under Project $W-152$ will allow for the flexibility to develop engineering and design concepts, and perform down-hole characterization to satisfy special project requirements at minimum cost and schedule. These special requirements may include hybrid well design in support of geophysical logging, subsurface wellhead design in high traffic areas and parking lots, design of small diameter piezoneters for water level measurements, and access for flowmeter measurements and vertical rad/chem profiling.

\subsection{QUALITY ASSURAKE}

The basis for establishing QA program requirements is the safety classification, as defined in WHC-CM-1-3, Managenent Requirements and Procedures, MRP 5.46, "Safety Classification of Systems, Components and Structures." The overall safety class for RCRA groundwater monitoring wells has been established as Safety Class 3, as documented in WHC-SD-EN-PLN-001, Safety Class Designation of Groundwater Monitoring Wells (WHC 1992).

\subsubsection{Quality Assurance Onsite}

Quality assurance activities for all contractors involved in design, construction, and testing of the project shall be formulated and executed in accordance with the project-specific quality assurance plan (WHC-CM-4-2, QI 2.1) and must meet the quality assurance requirements of the Tri-Party Agreement, as applicable. Program requirements establ ished in the quality assurance plan shall be consistent with DOE Order 5700.6C, Quality Assurance.

\subsubsection{Interface Coordination}

The successful completion of Project $\mathrm{W}-152$ will be achieved through meetings and planned discussions to resolve conflicts or problems. WHC review and approval of ensuing documents will be defined in accordance with WHC-CM-6-1, EP 1.6, "Engineering Data Transmitta1," EP 1.7, "Engineering Document Approval and Release Requirements," and EP 2.2, "Engineering Document Change Control." Interface responsibilities for the various facilities involved will be defined in the project-specific quality assurance program plan and interface requirements for the project will be defined in accordance with WHC-CM-6-1, EP 1.5, Interface Control. 
WHC-SD-EN-FDC-002, Rev 1

This page intentionally left blank. 


\subsection{CODES ND STAWARDS}

Design and construction shall be in accordance with the following DOE orders. For each DOE order, the DOE-Headquarters order is followed by the corresponding DOE-RL order as applicable.

- DOE Order 232.1, Occurrence Reporting and Processing of Operations Information

- DOE Order 5400.2A, Environmental Conpliance Issue Coordination

- DOE Order 5400.5, Radiation Protection of the Public and the Environment

- DOE Order 5480.3, Safety Requirenents for the Packaging and Transportation of Hazardous Materials, Hazardous Substances, and Hazardous Wastes

- DOE Order 5480.9A, Construction Project Safety and Health Management

- DOE Order 5480.17, Site Safety Representatives

- DOE Order 5484.1, Environnental Protection, Safety, and Health Protection Information Reporting Requirenents DOE-RLIP 5484.1, Environnental Protection, Safety, and Health Protection Information Reporting Requirements

- DoE Order 6430.1A, General Design Criteria (-99 sections do not apply)

- DOE 5700.6C, Quality Assurance.

Design and construction shall be in accordance with the following Federal and state regulations, and applicable references within regulations, codes, and standards:

- 29 CFR 1910, "Hazardous Waste Operations and Emergency Response"

- 40 CFR 264, "Environmental Protection Agency Regulations for Owners and Operators of Permitted Hazardous Waste Facilities"

- 40 CFR 265, "Environmental Protection Agency Interim Status Standards for Owners and Operators of Hazardous Waste Facilities"

- WAC 173-160, "Minimum Standards for the Construction and Maintenance of Wells"

- WAC 173-162, "Rules and Regulations Governing the Regulation and Licensing of We11 Contractors and Operators"

- WAC 173-303, "Dangerous Waste Regulations"

- WAC 173-304, "Minimum Functional Standards for Solid Waste Handling." 
WHC-SD-EN-FDC-002, Rev 1

This page intentionally left blank. 
MHC-SD-EN-FDC-002, Rev 1

\subsection{REFEREMES}

29 CFR 1910, "Hazardous Waste Operations and Emergency Response," Code of Federal Regulations, as amended.

40 CFR 264, "Environmental Protection Agency Regulations for Owners and Operators of Permitted Hazardous Waste Facilities," Code of Federal Regulations, as amended.

40 CFR 265, "Environmental Protection Agency Interim Status Standards for Owners and Operators of Hazardous Waste Facilities," Code of Federal Regulations, as amended.

Comprehensive Environaental Response, Compensation, and Liability Act of 1980 , 42 USC 9601, et seq.

DOE, 1984, Environiental Protection, Safety, and Health Protection Standards, DOE Order 5484.1, U.S. Department of Energy, Washington, D.C.

DOE, 1985, Safety Requirenents for the Packaging and Transportation of Hazardous Materials, Hazandous Substances, and Hazardous Wastes, DOE Order 5480.3, U.S. Department of Energy, Washington, D.C.

DOE, 1986, Safety Analysis and Review Systen, DOE Order 5481.1B, U.S. Department of Energy, Washington, D.C.

DOE, 1988, Site Safety Representatives, DOE Order 5480.17, U.S. Department of Energy, Washington, D.C.

DOE, 1989, Environnental Compliance Issue Coordination, DOE Order 5400.2A, U.S. Department of Energy, Washington, D.C.

DOE, 1989, General Design Criteria, DOE Order 6430.1A, U.S. Department of Energy, Washington, D.C.

DOE, 1990, Radiation Protection of the Public and the Environment, DOE Order 5400.5, U.S. Department of Energy, Mashington, D.C.

DOE, 1991, Quality Assurance, DOE Order 5700.6C, U.S. Department of Energy, Washington, D.C.

DOE, 1994, Construction Project Safety and Health Managenent, DOE Order 5480.9A, U.S. Department of Energy, Washington, D.C.

DOE, 1995, Occurrence Reporting and Processing of Operations Information, DOE Order 232.1, U.S. Department of Energy, Washington, D.C.

DOE-RL, 1992, "Categorical Exclusion for Installation and Monitoring of RCRA and Related Groundwater Monitoring Systems, Hanford Site", 91-EAB-150, U.S. Department of Energy, Richland Operations Office, Richland, Washington. 
DOE-RL, 1993, Environmental Protection, Safety, and Health Protection Standards, DOE-RLIP 5484.1, U.S. Department of Energy, Rich land Operations office, Richland, Hashington.

DOE-RL, 1994, Hanford Site Environmental Monitoring Plan, DOE/RL-91-50, Rev 1, U.S. Department of Energy, Richland Operations Office, Richland, Washington.

Ecology, EPA, and DOE, 1994, Hanford Federal Facility Agreement and Consent Order, as amended, Washington State Department of Ecology, U.S. Environmental Protection Agency, and U.S. Department of Energy, Olympia, Washington.

EPA, 1986, RCRA Groundwater Monitoring Technical Enforcement Guidance Document, OSWER-9950.1, U.S. Environmental Protection Agency, Washington, D.C.

EPA, 1992, RCRA Groundwater Monitoring: Draft and Technical Guidelines, U.S. Environmental Protection Agency, Washington, D.C.

Hazardous and Solid Waste Amendment of 1989, HSWA 3004, et seq.

HSRCM-1, Rev. 2, Hanford Site Radiological Control Manual, Westinghouse Hanford Company, Richland, Washington.

National Envirommental Policy Act of 1969, 42 USC 4321, et seq.

Occupational Safety and Health Act of 1970, 29 USC 651, et seq.

Resource Conservation and Recovery Act of 1976, 42 USC 6901, et seq.

WAC-173-160, "Minimum Standards for the Construction and Maintenance of Wells," Washington Administrative Code, as amended.

WAC-173-162, "Rules and Regulations Governing the Regulations and Licensing of Wel1 Contractors'" Washington Adwinistrative Code, as anended.

WAC 173-303, "Dangerous Waste Regulations," Washington Administrative Code, as amended.

WAC 173-304, "Minimum Functional Standards for Solid Waste Handling," Washington Administrative Code, as amended.

WHC-S-014, Generic Well Specification, Rev. 7, Westinghouse Hanford Company, Richland, Washington.

WHC, 1989, Strategy for Handling and Disposing of Purgewater at the Hanford Site, Washington, WHC-MR-0039, Westinghouse Hanford Company, Richland, Washington.

WHC, 1992, Safety Class Designation of Groundwater Monitoring Wells, WHC-SD-EN-PLN-001, West inghouse Hanford Company, Richland, Washington. 
WHC-CM-1-10, Safety Manual, Mestinghouse Hanford Company, Richland, Washington.

WHC-CH-4-33, Security Manual, Westinghouse Hanford Company, Richland, Mashington.

WHC-CM-5-16, Hazardous Waste Management, Westinghouse Hanford Company, Richland, Washington.

MHC-CM-6-1, Standard Engineering Practices, Westinghouse Hanford Company, Richl and, Washington.

WHC-CM-7-5, Environmental Compliance, Westinghouse Hanford Company, Richland, Washington.

WHC-CM-7-7, Environmental Investigations and Site Characterization Manual, Westinghouse Hanford Company, Richland, Washington. 
WHC-SD-EN-FDC-002, Rev 1

This page intentionally left blank. 
WHC-SD-EN-FDC-002, Rev 1

APPEMDIX A

DESIEN eUIDANCE

A-i 
WHC-SD-EN-FDC-002, Rev 1

This page intentionally left blank.

A- $\mathbf{i} \mathbf{i}$ 


\section{APPEDIX $\boldsymbol{A}$}

\section{DESTEY EUTDANCE}

This appendix is for Architect-Engineer information only.

In designing the monitoring wells and the layout of both the initial work and the final design for the monitoring systems, extensive use and evaluation should be made of available information. This information includes:

- Open literature information

- Draft technical guidance provided by regulatory agencies

- Experience gained by the design of previous groundwater monitoring systems (i.e., design of individual monitoring wells, design of the

- total system, drilling techniques, well completion techniques, and hydrogeologic testing and characterization)

- Experience in drilling monitoring wells at the Hanford Site.

In reference to the latter two items, the following should be evaluated:

- Detection groundwater monitoring systems previously installed under Project $\mathrm{W}-017$ at the A-36B Crib, B Pond, Grout Treatment Facility, Low-level Burial Grounds, single-shell tanks, S-10 Ditch and Pond, and U-12 Crib

- Assessment monitoring systems installed at the 183-H Solar Evaporation Basin, 300 Area Process Trenches, $100 \mathrm{~K}$ Basins, and the 216-U-12 Crib

- A Detection-Level Hazardous Waste Ground-Water Monitoring Compliance Plan for the 200 Areas Low-Level Burial Grounds and Retrievable Storage Units, "Engineering Study," and Appendix C, "Well Specifications" (statement of work), U.S. Department of Energy, Rich1 and Operations Office, February 1987, Appendix B

- Installation of Groundwater Monitoring Wells in Support of the 100-K Fuel Storage Basins, WHC-SD-EN-AP-153, Rev. 1, Westinghouse Hanford Company, May 1994. 
WHC-SD-EN-FDC-002, Rev 1

This page intentionally left blank.

A-2 


\begin{tabular}{|c|c|c|c|c|c|c|}
\hline \multicolumn{7}{|c|}{ DISTRIBUTION SHEET } \\
\hline To & \multirow{2}{*}{\multicolumn{3}{|c|}{$\begin{array}{l}\text { From } \\
\text { B. A. Willians }\end{array}$}} & & \multicolumn{2}{|l|}{ Page I of 1} \\
\hline Distribution & & & & & \multicolumn{2}{|c|}{ Date July 18,1995} \\
\hline \multicolumn{5}{|l|}{ Project TitleN Work Order } & \multicolumn{2}{|l|}{ EDT No. N/A } \\
\hline \multicolumn{5}{|c|}{$\begin{array}{l}\text { Functional Design Criteria for FY 1993-2000 Groundwater } \\
\text { Monitoring Wells }\end{array}$} & \multicolumn{2}{|c|}{ ECN No. 618187} \\
\hline Name & & MSIN & $\begin{array}{c}\text { Text } \\
\text { With All } \\
\text { Attach. }\end{array}$ & Text Only & $\begin{array}{c}\text { Attach./ } \\
\text { Appendix } \\
\text { Only }\end{array}$ & $\begin{array}{l}\text { EDT/ECN } \\
\text { Only }\end{array}$ \\
\hline $\begin{array}{l}\text { M. R. Adams } \\
\text { D. M. Collado } \\
\text { D. G. Farwick } \\
\text { M. J. Furman } \\
\text { M. G. Gardner } \\
\text { D. J. Hart } \\
\text { J. F. Keller } \\
\text { J. R. Kelly } \\
\text { J. S. Schmid } \\
\text { W. R. Thackaberry } \\
\text { R. R. Thompson } \\
\text { W. E. Toebe } \\
\text { C. W. Walton } \\
\text { B. A. Williams } \\
\text { J. B. Witt } \\
\text { M. T. York }\end{array}$ & & $\begin{array}{l}H 6-06 \\
\text { A5-18 } \\
H 4-16 \\
S 7-55 \\
S 3-24 \\
T 3-05 \\
\text { L4-93 } \\
\text { R3-28 } \\
\text { H6-06 } \\
\text { H6-32 } \\
H 6-32 \\
H 6-22 \\
\text { L4-01 } \\
\text { H6-06 } \\
\text { L4-93 } \\
\text { H6-32 }\end{array}$ & $\begin{array}{l}x \\
X \\
X \\
x \\
x \\
X \\
X \\
X \\
X \\
X \\
X \\
X \\
X \\
X \\
X \\
X\end{array}$ & & & \\
\hline $\begin{array}{l}\text { EDMC } \\
\text { Central Files }\end{array}$ & & $\begin{array}{l}H 6-08 \\
A 3-38\end{array}$ & $\begin{array}{l}x \\
x\end{array}$ & & & \\
\hline
\end{tabular}

